\title{
Matrix attachment regions as a tool to influence plant transgene expression
}

\author{
Anna Sergeevna Dolgova ${ }^{1,2}$ (1) $\cdot$ Sergey Vladimirovich Dolgov ${ }^{3}$
}

Received: 22 January 2019 / Accepted: 8 April 2019 / Published online: 12 April 2019

(c) King Abdulaziz City for Science and Technology 2019

\begin{abstract}
The inclusion of special regulatory sequences known as matrix attachment regions (MARs) in transgene constructs has been suggested as a possible approach to stabilise the expression of foreign heterological genes. The present review provides a brief summary regarding the MARs that have been used in investigations studying their influence on plant transgene expression in different plants with different promoters and reporter genes, and the comparison of these investigations.
\end{abstract}

Keywords Transgenic plant $\cdot$ Matrix attachment regions $\cdot$ MAR $\cdot$ Transgene expression

\section{Introduction}

Plant transformation is based on the ability to integrate foreign DNA into the genomes of host plants and on the efficiency of the transformed cell to develop into the whole plant. The development of various methods for genetic transformation led to the application of transgenic plants in various spheres, such as improvement of the commercial traits of a large number of agricultural crops, high-level production of important proteins in plants and the usage of transgenic plants as an instrument for the explanation of a gene's working machinery (Lloyd 2003; Kusaba 2004). The use of transgene technology allows improvement of certain plant traits, including disease resistance, stress tolerance, enhanced nutrition and male sterility (Lanfranco 2003). However, considerable variability in transgene expression has been observed within the limits of plant populations transformed using identical expression constructs and methods under identical conditions (Peach and Velten 1991; Bennet 1993; Birch 1997; Bhat and Srinivasan 2002; Butaye et al. 2004; Dolgova et al. 2015). This variability in expression greatly complicates the analysis of phenotypical traits

Anna Sergeevna Dolgova

annadolgova@inbox.ru

Central Research Institute of Epidemiology, Moscow, Russia

2 Saint-Petersburg Pasteur Institute, St. Petersburg, Russia

3 Biotron, Branch of Shemyakin and Ovchinnikov Institute of Bioorganic Chemistry, Puschino, Russia as well as the development of commercially profitable crops with predictable characteristics. To reduce the cost, efforts, and number of mistakes by researchers, many approaches have been explored to achieve stable transgene expression and predict the level of this expression. The variability in transgene expression is influenced by several factors. One of these factors is the integration site, which includes the chromatin status (heterochromatic or euchromatic) and the influence of nearby regulatory sequences (enhancers or silencers). Additionally, transgene expression may be affected by the number and disposition of transgenes within the integration site (a single copy or multiple copies arranged as inverted or direct repeats).

Generally, the result of a genetic transformation is a high frequency of transgenic plants with undesirable and unpredictable levels of gene expression, along with a considerable number of transformants, in a definite proportion, with low, although expected, expression levels. For instance, this kind of result was observed in previous studies for standard reporter genes such as the gene for beta-glucuronidase protein (uidA) (Hobbs et al. 1993; Elmayan and Vaucheret 1996; Brouwer et al. 2002; De Bolle et al. 2003; Dolgova et al. 2015). Moreover, plants with desirable expression levels may lose these characteristics within a few generations (Scheid et al. 1991; Bhat and Srinivasan 2002; Vain et al. 2002; Butaye et al. 2004). Additionally, the variability in transgene expression raises the inconvenience of using a large number of plants for the analysis to discover individual transformants with acceptable levels of expression and desired phenotypes, and therefore further complicates 
the interpretation of outcomes of the conducted research (Birch 1997; Bhat and Srinivasan 2002; De Bolle et al. 2003). Therefore, one of the main objectives in the field of plant transformation is to design vectors and methods that can produce a high percentage of transgenic plants with the required stable phenotype and minimum differences in the expression levels among individual plants. These problems have stimulated the search for tools that would be able to reduce variations in transgene expression. The inclusion of special regulatory sequences known as matrix attachment regions (MARs) in the transgene constructs has been suggested as a possible approach to stabilise transgene expression. Since the beginning of the 1990s, several experiments have been conducted in an attempt to understand the machinery through which MARs influence the transgene expression in plants and plant cell cultures. However, to date, no complete review of these elements and the consequences of their application in plants is available. In the present review, studies (Table 1) on this subject have been summarised, and a brief overview of the MARs, model plants, promoters and reporter genes used in these studies has been provided.

\section{MARs: what are they?}

DNA sequences possessing the ability to bind to the nuclear matrix were named MARs (matrix/scaffold attachment regions), or SARs or MAR elements. These are non-transcribed, 100-3000 bp AT-rich fragments of the eukaryotic genome, which possess the ability to bind to the isolated nuclear matrix. The majority of the earlier reports that aimed at studying the effects of MAR elements were generally based on the hypothesis that the variability in transgene expression could be explained by accidental integration of the vector into the target genome. The attachment of MARs to the nuclear scaffold is supposed to protect the transgenes from the regulatory influence of neighbouring genes or chromatin. Recent research has demonstrated that plant genes containing predicted MAR sequences exhibit significantly lower differential expression profile index (DEXP) values and are likely to be expressed in one tissue, organ or developmental phase (Tetko et al. 2006). Several experiments have been conducted to identify the specific role of MAR sequences in influencing the stability of the integrated transgenes. The animal transgene expression experiments that used MAR elements demonstrated that in most cases, MARs enhanced the usual levels of expression and reduced expression variability. The investigations involving plant subjects have not been as comprehensive, as these began considerably later, and therefore, such definite resuming of expression level could not be suggested. In the initial stages, it was believed that the studies on plant systems could not be carried out as completely as the ones conducted on animals.
However, the results of the scientific investigations conducted on animals in the later stages were greatly different from the earlier animal experiments (Poljak et al. 1994; Kalos and Fournier 1995), which implies that this statement must be stricter. It may not be possible to squeeze the large amount of conflicting data from plant studies into the frames of the total contradictory data of all the biological systems.

\section{Plants}

Nicotiana tabacum has long served as a key model plant for the development of transformation technology, transgene integration and analysis of expression stability. This may be because tobacco was the first plant for which it was possible to achieve in vitro regeneration (Skoog and Miller 1957) and to develop a standard cell culture medium (Murashige and Skoog 1962). It is the most studied plant subject, and the techniques for its transformation are well established. All initial and significant modern studies regarding the MAR influence on plant transgene expression were conducted on the cultures of this plant subject. Different tobacco parts have been used in these experiments (Table 1), mostly whole plants; although, callus cultures, cells, seeds and leaves have also been used. The results of the early experiments on tobacco plant systems (Breyne et al. 1992) surprisingly differed from the majority of the data based on animal experiments published during those times. The results of a study conducted in 1993 (Schöffl et al. 1993) were somewhat closer to what was expected on the basis of animal experiments. The application of MAR elements led to a fivefold to ninefold increase in the expression of the betaglucuronidase protein (GUS) reporter gene, while it exerted no influence on the variability in expression. However, it at least partly noted the dependence of expression on the gene copy number. Research papers published in the years 1994 and 1995 (Mlynarova et al. 1994, 1995) reported that the expression levels exhibited no dependence on the gene copy number, as opposed to the findings of the previous study (Schöffl et al. 1993), although this was in agreement with the studies conducted on animals (Poljak et al. 1994). Among the subsequent studies conducted on plants, the most similar ones to the animal experiments were those in which ballistic transformation or cell culturewas used (Allen et al. 1993, 1996; Mankin et al. 2003). The results of later studies revealed that the abnormal strong effect of MARs which was observed in the tobacco suspension cell culture transformed by microprojectile bombardment (Allen et al. 1993, 1996) was most likely because of the rapidly dividing, undifferentiated cells, rather than due to certain unique advantages of the MARs or the complexity of insertion events obtained using direct DNA delivery (Ülker et al. 1999). In the experiment using T-DNA transformation, the expression levels of the reporter gene were much lower in tobacco cells compared to plants, and the influence of MAR 
Table 1 Influence of MARs on transgene expression in different plant species and organ cultures

\begin{tabular}{|c|c|c|c|c|c|c|}
\hline Plant system & $\begin{array}{l}\text { MAR source } \\
\text { (name) }\end{array}$ & Promoter-reporter & $\begin{array}{l}\text { DNA transfer } \\
\text { method }\end{array}$ & $\begin{array}{l}\text { Influence on } \\
\text { expression level }\end{array}$ & $\begin{array}{l}\text { Influence on } \\
\text { expression vari- } \\
\text { ability }\end{array}$ & Sources \\
\hline \multirow[t]{2}{*}{ Tobacco callus } & Soy-bean (P1) & NOS-GUS & T-DNA & $2 \times$ decrease & $2 \times$ decrease & Breyne et al. (1992) \\
\hline & $\begin{array}{l}\text { Human ( } \beta \text {-globin } \\
\text { SAR) }\end{array}$ & NOS-GUS & T-DNA & Little influence & Little decrease & \\
\hline Tobacco plants & Soy-bean $\left(\mathrm{SAR}_{\mathrm{L}}\right)$ & Heat Shock-GUS & T-DNA & $5-9 \times$ increase & No influence & Schöffl et al. (1993) \\
\hline Tobacco cells & Yeast (ARS-1) & 35S-GUS & Biolistic & $12 \times$ increase & Little & Allen et al. (1993) \\
\hline Tobacco plants & $\begin{array}{l}\text { Chicken (A ele- } \\
\text { ment) }\end{array}$ & Lhca3-GUS & T-DNA & $3-4 \times$ increase & $3-8 \times$ decrease & $\begin{array}{l}\text { Mlynarova et al. } \\
\text { (1994) }\end{array}$ \\
\hline Tobacco seeds & Bean (phas MAR) & Phaseolin-GUS & T-DNA & $3 \times$ increase & $2 \mathrm{x}$ decrease & $\begin{array}{l}\text { van der Geest et al. } \\
\text { (1994) }\end{array}$ \\
\hline Tobacco cells & Petunia (TBS) & 35S-GUS & Biolistic & No influence & $\begin{array}{l}7.8-16 \times \text { increase } \\
\text { in transformation } \\
\text { frequencies }\end{array}$ & $\begin{array}{l}\text { Buising and Ben- } \\
\text { bow (1994) }\end{array}$ \\
\hline Maize cells & & & & & $\begin{array}{l}\text { 1.7-2.4×increase } \\
\text { in transformation } \\
\text { frequencies }\end{array}$ & \\
\hline \multirow[t]{2}{*}{ Tobacco plants } & $\begin{array}{l}\text { Chicken (A ele- } \\
\text { ment) }\end{array}$ & Enh35S-GUS & T-DNA & $2 \times$ increase & $2-7 \times$ decrease & \multirow[t]{2}{*}{$\begin{array}{l}\text { Mlynarova et al. } \\
\text { (1995) }\end{array}$} \\
\hline & $\begin{array}{l}\text { Chicken (A ele- } \\
\text { ment) }\end{array}$ & NOS -NPTII & T-DNA & No influence & Up to $3 \times$ decrease & \\
\hline Tobacco cells & Tobacco (RB7) & 35S-GUS & Biolistic & $60 x$ increase & No influence & Allen et al. (1996) \\
\hline $\begin{array}{l}\text { Tobacco seeds } \\
\text { Tobacco leaf disk }\end{array}$ & Bean (phas MAR) & P109-GUS & T-DNA & No influence & No data & $\begin{array}{l}\text { van der Geest and } \\
\text { Hall (1997) }\end{array}$ \\
\hline Tobacco leaf disk & Tobacco (RB7) & 35S-GUS & T-DNA & $1.6 \times$ increase & $\begin{array}{l}\text { Increase of the } \\
\text { number of GUS } \\
\text { foci }\end{array}$ & \multirow[t]{3}{*}{ Han et al. (1997) } \\
\hline $\begin{array}{l}\text { Poplar explants }(P . \\
\text { tremula } \mathrm{x} \text { P.alba } \\
\text { clone } 717)\end{array}$ & Tobacco (RB7) & 35S-GUS & T-DNA & $8.7 \times$ increase & Little & \\
\hline $\begin{array}{l}\text { Poplar explants }(P . \\
\text { trichocarpax } \mathrm{x} \\
\text { P.deltoides clone } \\
184-402)\end{array}$ & Tobacco (RB7) & 35S-GUS & T-DNA & $7.7 \times$ increase & Little & \\
\hline Tobacco plants & Pea (vic MAR) & 35S-GUS & T-DNA & Little & Little & \multirow{2}{*}{$\begin{array}{l}\text { Liu and Tabe } \\
\text { (1998) }\end{array}$} \\
\hline Tobacco plants & $\begin{array}{l}\text { Arabidopsis (At } \\
\text { MAR) }\end{array}$ & 35S-GUS & T-DNA & $5-10 \times$ increase & No influence & \\
\hline Maize cells & $\begin{array}{l}\text { Chicken (A ele- } \\
\text { ment) }\end{array}$ & 35S-cabl-GUS & Biolistic & $36 \times$ increase & Increase & $\begin{array}{l}\text { Odell and Krebbers } \\
\text { (1998) }\end{array}$ \\
\hline \multirow[t]{2}{*}{ Rice plants } & Tobacco (RB7) & 35S-GUS & Biolistic & $2.5 \times$ increase & Little & \multirow[t]{2}{*}{ Vain et al. (1999) } \\
\hline & Yeast (ARS-1) & 35S-GUS & Biolistic & $3 \times$ increase & Little & \\
\hline Tobacco plants & Tobacco (RB7) & 35S-GUS & Biolistic & $2 \times$ increase & Little & Ülker et al. (1999) \\
\hline Pine callus & Tobacco (RB7) & $\begin{array}{l}\text { Enh35S- } \\
\text { GUS:nptII }\end{array}$ & T-DNA & $3 \times$ increase & $\begin{array}{l}\text { Decrease of } \\
\text { the transgene } \\
\text { expression vari- } \\
\text { ability over time }\end{array}$ & Levee et al. (1999) \\
\hline \multirow[t]{2}{*}{ Rice plants } & \multirow[t]{2}{*}{ Tobacco (RB7) } & Act1-GFP & Biolistic & $\begin{array}{l}3.3- \\
18.4 \times \text { increase }\end{array}$ & \multirow[t]{2}{*}{ Conflict data } & \multirow[t]{2}{*}{ Cheng et al. (2001) } \\
\hline & & Act1-GUS & & $\begin{array}{l}376- \\
650 \times \text { increase }\end{array}$ & & \\
\hline Tobacco plants & Pea & 35S-GUS & T-DNA & $2 \times$ increase & No data & Li et al. (2001) \\
\hline Tobacco plants & Synthetic (sMAR) & 35S-GUS & T-DNA & $2-2.5 \times$ increase & Increase & Nowak et al. (2001) \\
\hline
\end{tabular}


Table 1 (continued)

\begin{tabular}{|c|c|c|c|c|c|c|}
\hline Plant system & $\begin{array}{l}\text { MAR source } \\
\text { (name) }\end{array}$ & Promoter-reporter & $\begin{array}{l}\text { DNA transfer } \\
\text { method }\end{array}$ & $\begin{array}{l}\text { Influence on } \\
\text { expression level }\end{array}$ & $\begin{array}{l}\text { Influence on } \\
\text { expression vari- } \\
\text { ability }\end{array}$ & Sources \\
\hline \multirow[t]{2}{*}{ Tobacco plants } & $\begin{array}{l}\text { Chicken (A ele- } \\
\text { ment) }\end{array}$ & 35S-LUC & T-DNA & Little & No influence & \multirow[t]{2}{*}{$\begin{array}{l}\text { van Leeuwen et al. } \\
\text { (2001) }\end{array}$} \\
\hline & $\begin{array}{l}\text { Chicken (A ele- } \\
\text { ment) }\end{array}$ & 35S-LUC & T-DNA & $2 \times$ decrease & Increase & \\
\hline \multirow[t]{2}{*}{ Barley callus } & Soy-bean (P1) & 35S-GUS & Biolistic & $2 \times$ increase & $2 \times$ decrease & \multirow{2}{*}{$\begin{array}{l}\text { Petersen et al. } \\
\text { (2002) }\end{array}$} \\
\hline & Petunia (TBS) & 35S-GUS & Biolistic & No influence & $\begin{array}{l}\text { Increase trans- } \\
\text { formation } \\
\text { frequency }\end{array}$ & \\
\hline \multirow[t]{2}{*}{ Arabidopsis plants } & Yeast (ARS-1) & APT-Lc & T-DNA & Little decrease & Little & \multirow{2}{*}{$\begin{array}{l}\text { Holmes-Davis and } \\
\text { Comai (2002) }\end{array}$} \\
\hline & $\begin{array}{l}\text { Tomato (HSC80 } \\
\text { MAR) }\end{array}$ & APT-Lc & T-DNA & No influence & No data & \\
\hline \multirow[t]{5}{*}{ Tobacco plants } & Tobacco (TM1) & 35S-GUS & T-DNA & $1.5 \times$ fold & No influence & \multirow[t]{5}{*}{ Zhang et al. (2002) } \\
\hline & Tobacco (TM2) & & & $5 \times$ fold & & \\
\hline & Tobacco (TM3) & & & $1.35 \times$ fold & & \\
\hline & $\begin{array}{l}\text { Arabidopsis } \\
\text { (AM1) }\end{array}$ & & & $1.3 \times$ fold & & \\
\hline & $\begin{array}{l}\text { Arabidopsis } \\
\text { (AM2) }\end{array}$ & & & No influence & & \\
\hline \multirow[t]{6}{*}{ Tobacco cells } & \multirow[t]{6}{*}{ Tobacco (RB7) } & PsFed1-GUS & Biolistic & No influence & No influence & \multirow{6}{*}{$\begin{array}{l}\text { Mankin et al. } \\
(2003)\end{array}$} \\
\hline & & AtAhas-GUS & & No influence & Decrease in the & \\
\hline & & GmHspL-GUS & & 2.7-3.1 increase & number of lov & \\
\hline & & 35S-GUS & & $4.2-5.3 \times$ increase & $\begin{array}{l}\text { expressing trans- } \\
\text { formants }\end{array}$ & \\
\hline & & NOS-GUS & & $3-4.9 \times$ increase & & \\
\hline & & OCS-GUS & & $\begin{array}{l}8.3- \\
15.3 \times \text { increase }\end{array}$ & & \\
\hline \multirow[t]{3}{*}{ Maize plants } & Maize (P-MAR) & P1-rr-GUS & Biolistic & No influence & No influence & \multirow{3}{*}{$\begin{array}{l}\text { Sidorenko et al. } \\
\text { (2003) }\end{array}$} \\
\hline & \multirow{2}{*}{$\begin{array}{l}\text { Maize (Adh1 5'fr- } \\
\text { MAR) }\end{array}$} & WP-GUS & & & & \\
\hline & & Rsyn7-GUS & & & Decrease & \\
\hline \multirow[t]{3}{*}{ Tobacco cells } & \multirow{3}{*}{$\begin{array}{l}\text { Tobacco }(C H N 50 \\
\text { MAR) }\end{array}$} & 35S-GUS & T-DNA & $10 \times$ increase & No data & \multirow{3}{*}{$\begin{array}{l}\text { Fukuda and Nishi- } \\
\text { kawa (2003) }\end{array}$} \\
\hline & & 35S-GUS & T-DNA & No influence & & \\
\hline & & mini35S-GUS & T-DNA & Decrease & & \\
\hline Cacao plants & Tobacco (RB7) & 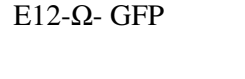 & T-DNA & $2.2 \times$ increase & $4.5 \times$ decrease & $\begin{array}{l}\text { Maximova et al. } \\
\text { (2003) }\end{array}$ \\
\hline $\begin{array}{l}\text { Gene silencing } \\
\text { Arabidopsis } \\
\text { mutants }\end{array}$ & $\begin{array}{l}\text { Chicken (A ele- } \\
\text { ment) }\end{array}$ & 35S-GUS & T-DNA & $5-12 \times$ increase & No influence & Butaye et al. (2004) \\
\hline Sorghum cells & Tobacco & Ubi-GUS & Biolistic & $2 \times$ increase & No influence & Able et al. (2004) \\
\hline Maize roots & $\begin{array}{l}\text { Maize (ADH1 5' } \\
\text { MAR) }\end{array}$ & Ubi-GUS & Biolistic & Increase & No data & Torney et al. (2004) \\
\hline Rice plants & Synthetic (SM11) & GOS2- GUS & Biolistic & $1.9 \times$ increase & Little & van der Geest et al. \\
\hline Arabidopsis plants & & Act2- GUS & T-DNA & $1.6-3.7 \times$ increase & $2.3-6.6 \times$ increase & (2004) \\
\hline Rice plants & $\begin{array}{l}\text { Chicken (BP- } \\
\text { MAR) }\end{array}$ & Act1-sGFP & T-DNA & Increase & Decrease & (Oh et al. 2005) \\
\hline Tobacco cells & Tobacco (RB7) & TripleOp-LUC & Biolistic & Increase & $\begin{array}{l}\text { Percentage } \\
\text { increase of } \\
\text { expressing cell } \\
\text { lines }\end{array}$ & $\begin{array}{l}\text { Abranches et al. } \\
\text { (2005) }\end{array}$ \\
\hline Tobacco plants & Tobacco (RB7) & 35S-TSWV-N & T-DNA & No data & $\begin{array}{l}1.5 \times \text { percentage } \\
\text { increase of lines } \\
\text { with resistance } \\
\text { to TSWV }\end{array}$ & Levin et al. (2005) \\
\hline
\end{tabular}


Table 1 (continued)

\begin{tabular}{|c|c|c|c|c|c|c|}
\hline Plant system & $\begin{array}{l}\text { MAR source } \\
\text { (name) }\end{array}$ & Promoter-reporter & $\begin{array}{l}\text { DNA transfer } \\
\text { method }\end{array}$ & $\begin{array}{l}\text { Influence on } \\
\text { expression level }\end{array}$ & $\begin{array}{l}\text { Influence on } \\
\text { expression vari- } \\
\text { ability }\end{array}$ & Sources \\
\hline Tobacco cells & Tobacco (RB7) & 35S-GFP & T-DNA & $2-3.7 \times$ increase & No data & $\begin{array}{l}\text { Halweg et al. } \\
\text { (2005) }\end{array}$ \\
\hline Rice callus & Tobacco (TM2) & $\begin{array}{l}\text { 35S-GUS } \\
\text { Ubi-GUS } \\
\text { PNZIP-GUS }\end{array}$ & T-DNA & $\begin{array}{l}3.2 \times \text { increase } \\
4.1 \times \text { increase } \\
2.3 \times \text { increase }\end{array}$ & $\begin{array}{l}\text { Decrease of } \\
\text { number of gene } \\
\text { silencing cal- } \\
\text { luses }\end{array}$ & Xue et al. (2005) \\
\hline Rice plant & & $\begin{array}{l}\text { 35S-GUS } \\
\text { Ubi-GUS } \\
\text { PNZIP-GUS }\end{array}$ & & $\begin{array}{l}5-6 \times \text { increase } \\
8-10 \times \text { increase } \\
4 \times \text { increase }\end{array}$ & No data & \\
\hline Arabidopsis plants & $\begin{array}{l}\text { Chicken (A ele- } \\
\text { ment) }\end{array}$ & 35S-GUS & T-DNA & No influence & No influence & $\begin{array}{l}\text { De Bolle et al. } \\
\text { (2007) }\end{array}$ \\
\hline $\begin{array}{l}\text { Gene silencing } \\
\text { Arabidopsis } \\
\text { mutants }\end{array}$ & $\begin{array}{l}\text { Tobacco (tab- } \\
\text { MAR) }\end{array}$ & 35S-GUS & T-DNA & $\begin{array}{l}\text { No influence } \\
5 \times \text { increase }\end{array}$ & & \\
\hline $\begin{array}{l}\text { Dunaliella salina } \\
\text { cells }\end{array}$ & D. salina (DSM 2) & RbcS-CAT & Electro-poration & $4.6 \times$ increase & $2.5 \times$ decrease & Wang et al. (2007) \\
\hline Poplar plants & Tobacco (RB7) & $\begin{array}{l}\text { 35S-GFP } \\
\text { RbcSTP-BAR }\end{array}$ & T-DNA & $\begin{array}{l}\text { No influence } \\
1.3 \times \text { decrease }\end{array}$ & $\begin{array}{l}\text { Significantly } \\
\text { reduced }\end{array}$ & Li et al. (2008) \\
\hline $\begin{array}{l}\text { Tobacco cells } \\
\text { Tobacco plants }\end{array}$ & Tobacco (TM2) & $\begin{array}{l}\text { 35S-GUS } \\
35 S-G U S \\
\text { 35Smini-GUS } \\
\text { PNZIP-GUS }\end{array}$ & T-DNA & $\begin{array}{l}5.2-6.5 \times \text { increase } \\
4.4-5.5 \times \text { increase } \\
\text { No influence } \\
6.8 \times \text { increase }\end{array}$ & No data & Zhang et al. (2009) \\
\hline Arabidopsis plants & $\begin{array}{l}\text { Maize (ADH1 5' } \\
\text { MAR) } \\
\text { Tobacco (RB7) } \\
\text { Petunia (TBS) }\end{array}$ & AGIP-GUS & T-DNA & $\begin{array}{l}\text { No influence } \\
\text { No influence } \\
76 \times \text { decrease }\end{array}$ & No data & Hily et al. (2009) \\
\hline Tobacco plants & $\begin{array}{l}\text { Rapeseed } \\
\text { (BnMAR) }\end{array}$ & 35S-GUS & T-DNA & $1.5 \times$ increase & No data & Xu et al. (2011) \\
\hline $\begin{array}{l}\text { Tobacco plants } \\
\text { (cv.Samsun) }\end{array}$ & Tobacco (Mf1) & 35S-Efb & T-DNA & $17 \times$ increase & No data & Festa et al. (2013) \\
\hline $\begin{array}{l}\text { Tobacco plants } \\
\text { (cv.81V9) }\end{array}$ & & & & $1.5 \times$ increase & & \\
\hline $\begin{array}{l}\text { Tobacco plants } \\
\text { (cv.NC89) }\end{array}$ & $\begin{array}{l}\text { Tobacco (RB7) } \\
\text { Tobacco (TM6) }\end{array}$ & $\begin{array}{l}35 S-G U S \\
\text { DREB-GUS } \\
\text { PNZIP-GUS } \\
\text { mini35S-GUS }\end{array}$ & T-DNA & $\begin{array}{l}6.5 \times \text { increase } \\
12.7 \times \text { increase } \\
4.3 \times \text { increase } \\
2.9 \times \text { increase } \\
9.8 \times \text { increase }\end{array}$ & No data & Ji et al. (2013) \\
\hline Tobacco leaves & Tobacco (RB7) & $\begin{array}{l}\text { 35S-NVCP } \\
35 S-I g G\end{array}$ & T-DNA & $\begin{array}{l}1.3 \times \text { increase } \\
3.4 \times \text { increase }\end{array}$ & No data & $\begin{array}{l}\text { Diamos et al. } \\
\text { (2016) }\end{array}$ \\
\hline Tobacco plants & $\begin{array}{l}\text { Petunia (Petun- } \\
\text { SAR) }\end{array}$ & 35S-GUS & T-DNA & $4.3 \times$ increase & Increase & $\begin{array}{l}\text { Dietz-Pfeilstetter } \\
\text { et al. (2016) }\end{array}$ \\
\hline Tobacco leaves & $\begin{array}{l}\text { Tobacco (RB7) } \\
\text { Tobacco (TM6) }\end{array}$ & 35S-GFP & T-DNA & $\begin{array}{l}3-40 \times \text { increase } \\
\text { Increase }\end{array}$ & No data & $\begin{array}{l}\text { Diamos and Mason } \\
\text { (2018) }\end{array}$ \\
\hline
\end{tabular}

elements was approximately the same (Zhang et al. 2009). Recent studies have demonstrated that in addition to tobacco plant parts, its cultivar could also be the reason for the differences observed in MAR effects (Festa et al. 2013). The validation and confirmation of these facts require a detailed and comprehensive study. In recent times, a method for testing different regulatory elements in transient plant expression systems has gained popularity. This technique was also used in the latest MAR experiments (Diamos et al. 2016,2018). This approach might allow rapid and effective evaluation of the 
functioning machinery of various MARs in different plant species other than tobacco.

In addition to tobacco, the most frequently used plants for MAR investigations are rice and Arabidopsis. Both A. thaliana and $N$. tabacum are the model organisms of choice for conducting research in plant biology. Currently, the transformation of Arabidopsis is highly reproducible and requires ordinary procedures. Moreover, a short life cycle, small plant size and efficient reproduction through self-pollination have allowed Arabidopsis to become an early favourite for studying induced mutations in plants (Koornneef and Meinke 2010). In the studies involving Arabidopsis, it was observed that the application of MARs from natural sources, such as yeast, tomato (HolmesDavis and Comai 2002), chicken and tobacco (De Bolle et al. 2007), could not enhance transgene expression in a wild-type background, although it could be used to enhance transgene expression in a mutant impaired in gene silencing (Butaye et al. 2004; De Bolle et al. 2007). Only the synthetic MARs assembled from sequence elements recognised by the nuclear matrix proteins and containing structural features commonly present in MARs led to an increase in reporter gene expression (van der Geest et al. 2004). In contrast to the results obtained with Arabidopsis, all of the MARs that were used in rice plants positively affected the transgene expression (Table 1), with approximately twice the effect observed in plants compared to the callus cultures (Xue et al. 2005). The RB7 action study conducted with poplar demonstrated a limited or negative effect of MAR elements on various aspects of transgene structure and stability, including the expression levels, year-to-year variation, position effect, T-DNA configuration and copy number, along with correlation in the expressions of co-integrated transgenes in these plants ( $\mathrm{Li}$ et al. 2008). The positive effect was observed only in immature explants (Han et al. 1997). In transgenic maize, only the chicken A element increased the reporter gene expression under the $35 \mathrm{~S}$ promoter (Odell and Krebbers 1998), while the combinations of maize MARs with maize (P1), wheat (WP) and synthetic (Rsyn7) promoters (Sidorenko et al. 2003) or with petunia (TBS) promoter (Buising and Benbow 1994) did not exhibit any such increase. MARs effects were also investigated in exotic cultures, such as pine callus (Levee et al. 1999), Sorghum cells (Able et al. 2004), Barley callus (Petersen et al. 2002), Theobroma cacao plants (Maximova et al. 2003) and Dunaliella salina cells (Wang et al. 2007); in all of these cases, the increase in the gene expression levels was approximately two-fourfold.

\section{MARs}

In the initial stages of investigations regarding the influence of MARs on transgene expression in plants, animal or yeast elements that had been characterised much earlier were used (Table 1). Human $\beta$-globin SAR did not result in an increase in the reporter gene expression levels, in contrast to what was expected (Breyne et al. 1992). Yeast ARS-1 was used three times, increasing the expression levels threefold in rice plants (Vain et al. 1999) and 12-fold in tobacco cells (Allen et al. 1993) when used in combination with the 35S promoter, and exhibiting no such functioning when used with the APT (adenine phosphoribosyltransferase) gene promoter from Arabidopsis (Holmes-Davis and Comai 2002). Chicken 5' MAR flanking the lysozyme locus was frequently used because it has been well characterised in animal models since the late 1980s (Loc and Strätling 1988). However, in the standard model system of $N$. tabacum plus $35 \mathrm{~S}$ promoter, the A element did not perform as expected (van Leeuwen et al. 2001; De Bolle et al. 2007). Chicken MAR resulted in a significant increase in the gene expression only in other plant species, such as maize cells (Odell and Krebbers 1998), gene silencing Arabidopsis mutants (Butaye et al. 2004) and rice (Oh et al. 2005), or with other gene promoters, such as Lhca3 or enhanced 35S (Mlynarova et al. 1995). Nevertheless, the A element refers to those rare MARs that are able to reduce variability in transgene expression (Mlynarova et al. 1994, 1995; Oh et al. 2005).

The most commonly used and the first-described MAR derived from plant subjects is the tobacco RB7 element from the root-specific gene (Conkling et al. 1990). This MAR operates stably in the tobacco plants, increasing the gene expression levels in conjunction with all tested promoters (Table 1), with the exception of just two-PsFed1 and AtAhas (Mankin et al. 2003). In mature poplar (Li et al. 2008) and Arabidopsis (Hily et al. 2009) plants, RB7 did not exert any influence on the reporter gene expression; however, in rice (Vain et al. 1999; Cheng et al. 2001) and cacao (Maximova et al. 2003), RB7 behaved the same way as in native tobacco. Thus far, RB7 is the most steadily working MAR among all the matrix attachment regions that have been tested in plant systems. Since the early 2000s, several novel tobacco MARs have been discovered (Table 1). The most promising one is tobacco MAR (TM) 2, which exhibits activity in tobacco with different promoters (Zhang et al. 2009), as well as in rice plants and callus cultures (Xue et al. 2005). MARs from other plants have not yet been widely studied.

Two Arabidopsis MAR sequences among the three that have been tested (Liu and Tabe 1998; Zhang et al. 2002), pea MARs (Liu and Tabe 1998; Li et al. 2001), bean beta-phaseolin MAR (van der Geest et al. 1994) and rapeseed BnMAR (Xu et al. 2011) relatively increased the expression levels of the uidA gene in tobacco. Petunia TBS, which was isolated 20 years ago (Meyer et al. 1988), is traditionally viewed together with the MAR elements, since its affinity towards the nuclear scaffold was established in 1995 (Galliano et al. 1995). Even so, TBS never increased the expression levels in the plants investigated (Table 1), and it possessed a set 
of functions different than those of the typical plant MARs (Hily et al. 2009). However, at the same time, it highly increased the transformation frequencies in tobacco, maize (Buising and Benbow 1994) and barley (Petersen et al. 2002) and was established as an enhancer-blocking insulator in Arabidopsis (Hily et al. 2009). A novel petunia element, Petun-SAR, possesses properties similar to the standard MARs, and increased the transgene expression in tobacco plants fourfold (Dietz-Pfeilstetter et al. 2016). Two synthetic MAR sequences were tested, namely sMAR, exhibiting increased reporter gene expression by twofold in tobacco (Nowak et al. 2001), and SM11 in Arabidopsis and rice (van der Geest et al. 2004). SM11 is the only known MAR that is able to increase transgene expression in non-mutant Arabidopsis. Although novel MARs are continuously being discovered (Wang et al. 2007; Festa et al. 2013), researchers in recent years have been increasingly adhering to verified MARs, such as RB7, while conducting their investigations (Ji et al. 2013; Diamos and Mason 2018).

\section{Promoter-reporter systems}

Over the past 40 years, the reporter gene uidA has held a leading position in all experiments involving plant transgene expression. The same is true for MAR studies; only a quarter of all the scientific research investigations involving MARs did not use this particular gene. Among the studies investigating the influence of MARs, six studies used the green fluorescent protein gene $(g f p)$ as a reporter (Cheng et al. 2001; Maximova et al. 2003; Oh et al. 2005; Halweg et al. 2005; Li et al. 2008; Diamos and Mason 2018), two studies used the luciferase luc gene (van Leeuwen et al. 2001; Abranches et al. 2005) and the other reporter genes were used only once in the studies, although the influence on the frequency of transformation was often assessed using the selective marker neomycin phosphotransferase II (NPTII). The variety of promoters used in the MARs investigations is large.

In the initial stages of plant transformation research, the promoters from tumour-inducing plasmids of $A$. tumefaciens were mainly used, such as the NOS promoter (Depicker et al. 1982). This promoter was also used in the first experiment conducted on the influence of MARs on transgene expression (Breyne et al. 1992). However, since the mid-1990s, the most commonly used promoter in MARs research is the constitutive cauliflower mosaic virus promoter $35 \mathrm{~S}$ (Table 1). The influence of different MARs on the expression driven by different promoters has been investigated (Table 1), although the understanding of pathway patterns has encountered obstruction by different experimental parameters. In an attempt to understand the mode of MAR influence, the effect of RB7 on six different promoters was analysed in stably transformed tobacco cell cultures (Mankin et al. 2003). The presence of MARs significantly increased the expression of transgenes under constitutive cauliflower mosaic virus (CaMV) 35S, nopaline synthase (NOS) and octopine synthase (OCS) promoters. On the other hand, the expression driven by an induced heat shock promoter (GmHspL) was increased by MAR only in the presence of heat shock. Moreover, this element did not exert any influence on the pea ferredoxin promoter (PsFed1), which is not normally expressed in this cell line, nor did it exhibit any influence on the Arabidopsis thaliana acetohydroxyacid synthase promoter (AtAhas). Therefore, it may be concluded that MARs increase the average GUS expression when used with an active promoter and exert little influence on the expression when applied in combination with promoters that are weak in use for a particular cell line or plant species. Similar results were obtained with another tobacco MAR, TM2, which was discovered later (Zhang et al. 2009). However, a novel MAR, TM6, enhanced transcription activation in transgenic tobacco independent of the promoters 35S, DREB, PNZIP or mini35S (Ji et al. 2013). Therefore, it is possible that MARs are a heterogeneous group of elements that share only the capacity of binding to the nuclear matrix (Holmes-Davis and Luca 1998), and their influence on transgene expression depends on both the promoter and their sequence.

\section{Conclusion}

MARs may have practical applications in plants to enhance the gene expression of commercially important proteins and facilitate the release of these proteins. Experiments have already been conducted using a target gene instead of reporter gene, such as the IgG coding gene, for which the immunogenicity of its product of expression was proven in mice models (Diamos et al. 2016), or using an MAR expression system in plants for an efficient production of bioactive Arabidopsis thaliana plant defensins (Sels et al. 2007). However, at this moment, there is no definite MAR element that would work in all conditions with equal effectiveness. The most universal today is tobacco RB7 MAR. From all conducted experiments, it failed to show positive activity in only two cases: mature poplar ( $\mathrm{Li}$ et al. 2008) and Arabidopsis (Hily et al. 2009). In tobacco itself (Table 1), in rice plants (Vain et al. 1999; Cheng et al. 2001) and even in an exotic culture such as cocoa (Maximova et al. 2003), the use of RB7 MAR led to a steady increase in the average level of expression, and in some cases to a decrease of the expression level variability. However, this element cannot be used for all purposes. This review will help to choose the correct MAR for a specific use, depending on what kind of plant, organs and tissue cultures you want to use, and what end result

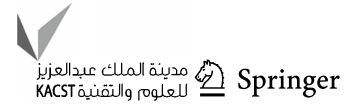


you need to achieve. Working with a certain culture, you can check the table and select the most appropriate element for required investigations or for use in biotechnology and biofarming. It is still necessary to continue research in the direction of understanding the functional concepts underlying MAR influence on transgene expression. However, right now, with the appropriate approach, you can use known MAR elements for high-efficiency transgene expression of target proteins for different usage.

Acknowledgements This study was supported by the Russian Science Foundation Grant \#17-75-10093.

\section{Compliance with ethical standards}

Conflict of interest On behalf of all authors, the corresponding author states that there is no conflict of interest.

\section{References}

Able JA, Rathus CO, Carroll BJ, Godwin ID (2004) Enhancing transgene expression levels in sorghum: current status and future goals. In: Seetharama N, Godwin ID (eds) Sorghum tissue culture and transformation. Oxford Publishers, New Delhi, pp 85-96

Abranches R, Shultz RW, Thompson WF, Allen GC (2005) Matrix attachment regions and regulated transcription increase and stabilize transgene expression. Plant Biotechnol J 3:535-543. https ://doi.org/10.1111/j.1467-7652.2005.00144.x

Allen GC, Hall GE Jr, Childs LC, Weissinger AK, Spiker S, Thompson WF (1993) Scaffold attachment regions increase reporter gene expression in stably transformed plant cells. Plant Cell 5:603-613

Allen GC, Hall G Jr, Michalowski S, Newman W, Spiker S, Weissinger AK, Thompson WF (1996) High-level transgene expression in plant cells: effects of a strong scaffold attachment region from tobacco. Plant Cell 8:899-913

Bennet J (1993) Genes for crop improvement. In: Setlow JK (ed) Genetic engineering, vol 15. Plenum, New York, pp 165-189

Bhat SR, Srinivasan S (2002) Molecular and genetic analyses of transgenic plants: considerations and approaches. Plant Sci 164:673-681

Birch RG (1997) Plant transformation: problems and strategies for practical application. Annu Rev Plant Physiol Plant Mol Biol 48:297-326

Breyne P, Van Montagu M, Depicker A, Gheysen G (1992) Characterization of a plant scaffold attachment region in a DNA fragment that normalizes transgene expression in tobacco. Plant Cell 4:463-471

Brouwer C, Bruce W, Maddock S, Avramova Z, Bowen B (2002) Suppression of transgene silencing by matrix attachment regions in maize: a dual role for the maize 5' ADH1 matrix attachment region. Plant Cell 14:2251-2264

Buising CM, Benbow RM (1994) Molecular analysis of transgenic plants generated by microprojectile bombardment: effect of petunia transformation booster sequence. Mol Gen Genet 243:71-81

Butaye K, Goderis I, Wouters P, Pues J, Delauré S, Broekaert W, Depicker A, Cammue B, De Bolle M (2004) Stable high-level transgene expression in Arabidopsis thaliana using gene silencing mutants and matrix attachment regions. Plant J 39:440-449

Cheng Z, Targolli J, Wu R (2001) Tobacco matrix attachment region sequence increased transgene expression levels in rice plants. Mol Breed 7:317-327
Conkling MA, Cheng C-L, Yamamoto YT, Goodman HM (1990) lsolation of transcriptionally regulated root-specific genes from tobacco. Plant Physiol 93:1203-1211

De Bolle MFC, Butaye KMJ, Coucke WJW, Goderis IJWM, Wouters PFJ, van Boxel N, Broekaert WF, Cammue BPA (2003) Analysis of the influence of promoter elements and a matrix attachment region on the inter-individual variation of transgene expression in populations of Arabidopsis thaliana. Plant Sci 165:169-179

De Bolle MF, Butaye KM, Goderis IJ, Wouters PF, Jacobs A, Delauré SL, Depicker A, Cammue BP (2007) The influence of matrix attachment regions on transgene expression in Arabidopsis thaliana wild type and gene silencing mutants. Plant Mol Biol 634:533-543

Depicker A, Stachel S, Dhaese P, Zambryski P, Goodman HM (1982) Nopaline synthase: transcript mapping and DNA sequence. J Mol Appl Genet 1:561-573

Diamos AG, Mason HS (2018) Chimeric 3' flanking regions strongly enhance gene expression in plants. Plant Biotechnol J. https://doi. org/10.1111/pbi.12931 [Epub ahead of print]

Diamos AG, Rosenthal SH, Mason HS (2016) 5' and 3' untranslated regions strongly enhance performance of geminiviral replicons in Nicotiana benthamiana Leaves. Front Plant Sci 7:200. https://doi. org/10.3389/fpls.2016.00200

Dietz-Pfeilstetter A, Arndt N, Manske U (2016) Effects of a petunia scaffold/matrix attachment region on copy number dependency and stability of transgene expression in Nicotiana tabacum. Transgenic Res 25(2):149-162. https://doi.org/10.1007/s1124 8-015-9924-2

Dolgova AS, Dolgov SV, Nazipova NN, Maksimenko OG, Georgiev PG (2015) Arabidopsis termination elements increase transgene expression in tobacco plants. Plant Cell Tissue Organ Cult 120(3):1107-1116. https://doi.org/10.1007/s11240-014-0667-1

Elmayan T, Vaucheret H (1996) Expression of single copies of a strongly expressed $35 \mathrm{~S}$ transgene can be silenced posttranscriptionally. Plant J 9:787-797

Festa M, Brun P, Piccinini R, Castagliuolo I, Basso B, Zecconi A (2013) Staphylococcus aureus Efb protein expression in Nicotiana tabacum and immune response to oral administration. Res Vet Sci 94(3):484-489. https://doi.org/10.1016/j.rvsc.2012.10.012

Fukuda Y, Nishikawa S (2003) Matrix attachment regions enhance transcription of a downstream transgene and the accessibility of its promoter region to micrococcal nuclease. Plant Mol Biol 51:665-675

Galliano H, Müller AE, Lucht JM, Meyer P (1995) The transformation booster sequence from Petunia hybrida is a retrotransposon derivative that binds to the nuclear scaffold. Mol Gen Genet 247:614-622. https://doi.org/10.1007/BF00290353

Halweg C, Thompson WF, Spiker S (2005) The Rb7 matrix attachment region increases the likelihood and magnitude of transgene expression in tobacco cells: a flow cytometric study. Plant Cell 17:418-429

Han KH, Ma C, Strauss SH (1997) Matrix attachment regions (MARs) enhance transformation frequency and transgene expression in poplar. Transgenic Res 6:415-420

Hily JM, Singer SD, Yang Y, Liu Z (2009) A transformation booster sequence (TBS) from Petunia hybrida functions as an enhancerblocking insulator in Arabidopsis thaliana. Plant Cell Rep 28(7):1095-1104. https://doi.org/10.1007/s00299-009-0700-8

Hobbs SLA, Warketin TD, DeLong CMO (1993) Transgene copy number can be positively or negatively associated with transgene expression. Plant Mol Biol 21:17-26

Holmes-Davis R, Comai L (2002) The matrix attachment regions (MARs) associated with the Heat Shock Cognate 80 gene (HSC80) of tomato represent specific regulatory elements. Mol Genet Genom 266:891-898 
Holmes-Davis R, Luca C (1998) Nuclear matrix attachment regions and plant gene expression. Trends Plant Sci 3(3):91-97

Ji L, Xu R, Lu L, Zhang J, Yang G, Huang J, Wu C, Zheng C (2013) TM6, a novel nuclear matrix attachment region, enhances its flanking gene expression through influencing their chromatin structure. Mol Cells 36(2):127-137. https://doi.org/10.1007/s1005 9-013-0092-z

Kalos M, Fournier REK (1995) Position-independent transgene expression mediated by boundary elements from the apolipoprotein B chromatin domain. Mol Cell Biol 15:198-207

Koornneef M, Meinke D (2010) The development of Arabidopsis as a model plant. Plant J 61(6):909-921. https://doi.org/10.1111/ j.1365-313X.2009.04086.X

Kusaba M (2004) RNA interference in crop plants. Curr Opin Biotechnol 15:139-143

Lanfranco L (2003) Engineering crops, a deserving venture. Riv Biol 96:31-54

Levee V, Garin E, Klimaszewska K, Seguin A (1999) Stable genetic transformation of white pine (Pinus strobus L.) after cocultivation of embryogenic tissues with Agrobacterium tumefaciens. Mol Breed 5:429-440

Levin JS, Thompson WF, Csinos AS, Stephenson MG, Weissinger AK (2005) Matrix attachment regions increase the efficiency and stability of RNA-mediated resistance to tomato spotted wilt virus in transgenic tobacco. Transgenic Res 14:193-206. https://doi. org/10.1007/s11248-004-5413-8

Li X, Zhu Z, Xu J, Wu Q, Xu H (2001) Isolation of pea matrix attachment region and study on its function in transgenic tobaccos. Sci China 44(4):400-408

Li J, Brunner AM, Meilan R, Strauss SH (2008) Matrix attachment region elements have small and variable effects on transgene expression and stability in field-grown Populus. Plant Biotechnol J 6(9):887-896

Liu JW, Tabe LM (1998) The influences of two plant nuclear matrix attachment regions (MARs) on gene expression in transgenic plants. Plant Cell Physiol 39:115-123

Lloyd A (2003) Vector construction for gene overexpression as a tool to elucidate gene function. Methods Mol Biol 236:329-344

Loc PV, Strätling WH (1988) The matrix attachment regions of the chicken lysozyme gene co-map with the boundaries of the chromatin domain. EMBO J 7(3):655-664

Mankin SL, Allen GC, Phelan T, Spiker S, Thompson WF (2003) Elevation of transgene expression level by flanking matrix attachment regions (MAR) is promoter dependent: a study of the interactions of six promoters with the RB7 3'MAR. Transgenic Res 12:3-12

Maximova S, Miller C, Antúnez de Mayolo G, Pishak S, Young A, Guiltinan MJ (2003) Stable transformation of Theobroma cacao L. and influence of matrix attachment regions on GFP expression. Plant Cell Rep 21(9):872-883

Meyer P, Kartzke S, Niedenhof I, Heidmann I, Bussmann K, Saedler H (1988) A genomic DNA segment from Petunia hybrida leads to increased transformation frequencies and simple integration patterns. Proc Natl Acad Sci USA 85(22):8568-8572

Mlynarova L, Loonen A, Heldens J, Jansen RC, Keizer P, Stiekema WJ, Nap JP (1994) Reduced position effect in mature transgenic plants conferred by the chicken lysozyme matrixassociated region. Plant Cell 6:417-426

Mlynarova L, Jansen RC, Conner AJ, Stiekema WJ, Nap JP (1995) The MAR-mediated reduction in position effect can be uncoupled from copy number-dependent expression in transgenic plants. Plant Cell 7:599-609

Murashige T, Skoog F (1962) A revised medium for rapid growth and bioassays with tobacco tissue cultures. Physiol Plant 15:473-479

Nowak W, Gawlowska M, Jarmolowski A, Augustyniak J (2001) Effect of nuclear matrix attachment regions on transgene expression in tobacco plants. Acta Biochim Pol 48:637-646
Odell JT and Krebbers E (1998). Enhanced transgene expression in a population of monocot cells employing scaffold attachment regions. World Patent Office

Oh SJ, Jeong JS, Kim EH, Yi NR, Yi SI, Jang IC, Kim YS, Suh SC, Nahm BH, Kim JK (2005) Matrix attachment region from the chicken lysozyme locus reduces variability in transgene expression and confers copy number-dependence in transgenic rice plants. Plant Cell Rep 24:145-154

Peach C, Velten J (1991) Transgene expression variability (position effect) of CAT and GUS reporter genes driven by linked divergent T-DNA promoters. Plant Mol Biol 17:49-60

Petersen K, Leah R, Knudsen S, Cameron-Mills V (2002) Matrix attachment regions (MARs) enhance transformation frequencies and reduce variance of transgene expression in barley. Plant Mol Biol 49:45-58

Poljak L, Seum C, Mattioni T, Laemmli UK (1994) SARs stimulate but do not confer position independent gene expression. Nucleic Acids Res 22:4386-4394

Scheid OM, Paszkowski J, Potrykus I (1991) Reversible inactivation of a transgene in Arabidopsis thaliana. Mol Gen Genet 228:104-112

Schöffl F, Schröder G, Kliem M, Rieping M (1993) An SAR sequence containing 395 bp DNA fragment mediates enhanced, genedosage-correlated expression of a chimaeric heat shock gene in transgenic tobacco plants. Transgenic Res 2:93-100

Sels J, Delauré SL, Aerts AM, Proost P, Cammue BP, De Bolle MF (2007) Use of a PTGS-MAR expression system for efficient in planta production of bioactive Arabidopsis thaliana plant defensins. Transgenic Res 16:531-538. https://doi.org/10.1007/ s11248-006-9057-8

Sidorenko L, Bruce W, Maddock S, Tagliani L, Li X, Daniels M, Peterson T (2003) Functional analysis of two matrix attachment region (MAR) elements in transgenic maize plants. Transgenic Res 12:137-154

Skoog F, Miller CO (1957) Chemical regulation of growth and organ formation in plant tissue cultured in vitro. Symp Soc Exp Biol 11:118-130

Tetko IV, Haberer G, Rudd S, Meyers B, Mewes H-W, Mayer KFX (2006) Spatiotemporal expression control correlates with intragenic scaffold matrix attachment regions (S/MARs) in Arabidopsis thaliana. PLoS Comput Biol 2(3):e21. https://doi.org/10.1371/ journal.pcbi.0020021

Torney F, Partier A, Says-Lesage V, Nadaud I, Barret P, Beckert M (2004) Heritable transgene expression pattern imposed onto maize ubiquitin promoter by maize adh-1 matrix attachment regions: tissue and developmental specificity in maize transgenic plants. Plant Cell Rep 22(12):931-938

Ülker B, Allen GC, Thompson WF, Spiker S, Weissinger AK (1999) A tobacco matrix attachment region reduces the loss of transgene expression in the progeny of transgenic tobacco plants. Plant $\mathbf{J}$ $18: 253-263$

Vain P, Worland B, Kohli A, Snape JW, Christou P, Allen GC, Thompson WF (1999) Matrix attachment regions increase transgene expression levels and stability in transgenic rice plants and their progeny. Plant J 18:233-242

Vain P, James A, Worland B, Snape W (2002) Transgene behaviour across two generations in a large random population of transgenic rice plants produced by particle bombardment. Theor Appl Genet 105:878-889

van der Geest AH, Hall TC (1997) The $\beta$-phaseolin 5' matrix attachment region acts as an enhancer facilitator. Plant Mol Biol 33:553. https://doi.org/10.1023/A:1005765525436

van der Geest AHY, Hall GE Jr, Spiker S, Hall TC (1994) The $\beta$-phaseolin gene is flanked by matrix attachment regions. Plant Mol Biol 6:413-423

van der Geest AH, Welter ME, Woosley AT, Pareddy DR, Pavelko SE, Skokut M, Ainley WM (2004) A short synthetic MAR

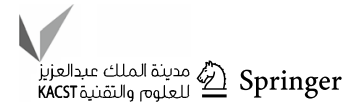


positively affects transgene expression in rice and Arabidopsis. Plant Biotechnol J 2:13-26. https://doi.org/10.104 6/j.1467-7652.2003.00044.x

van Leeuwen W, Mlynárová L, Nap JP, van der Plas LHW, van der Krol AR (2001) The effect of MAR elements on variation in spatial and temporal regulation of transgene expression. Plant Mol Biol 47:543-554

Wang T, Xue L, Hou W, Yang B, Chai Y, Ji X, Wang Y (2007) Increased expression of transgene in stably transformed cells of Dunaliella salina by matrix attachment regions. Appl Microbiol Biotechnol 76:651-657. https://doi.org/10.1007/s0025 3-007-1040-7

Xu MY, Zhang X, Zhang L, Luo YZ, Fan YL, Wang L (2011) Functional analysis of BnMAR element in transgenic tobacco plants.
Mol Biol Rep 38(5):3285-3291. https://doi.org/10.1007/s1103 3-010-0433-3

Xue H, Yang YT, Wu CA, Yang GD, Zhang MM, Zheng CC (2005) TM2, a novel strong matrix attachment region. isolated from tobacco, increases transgene expression in transgenic rice calli and plants. Theor Appl Genet 110:620-627

Zhang K, Wang J, Yang G, Guo X, Wen F, Cui D, Zheng C (2002) Isolation of a strong matrix attachment region (MAR) and identification of its function in vitro and in vivo. Chin Sci Bull 47(23):1999-2005

Zhang J, Lu L, Ji L, Yang G, Zheng C (2009) Functional characterization of a tobacco matrix attachment region-mediated enhancement of transgene expression. Transgenic Res 18:377-385 